\title{
Sufism: A Cultural Integration Potential
}

\author{
Dragan Kostovski \\ Saints "Cyril and Methodius" University of Skopje \\ Faculty of Philosophy
}

Received 30 May $2018 \cdot$ Revised 21 July $2018 \cdot$ Accepted 24 July 2018

\begin{abstract}
Europe's history is like a manuscript of divisions between East and West: a boundary that stretches more than a thousand years. This history is full with more or less unsuccessful examples of attempts where this boundary was to be thrown away or at least minimized to certain degree. But, the actual failure in these attempts doesn't mean that the impact left behind, moreover the religious impact in current social context is to be considered as rather irrelevant.
\end{abstract}

Keywords: multiculturalism, religious diversity, cultural integration, Islam mysticism, Sufism, foreign policy.

\section{Introduction}

The current processes of globalization that are founded by various activities throughout last century had their apex in creation of the international European Economic Community which will result in European Union: a way for economic proximity between various nations and cultures considering the complexity of the European continent.

Nevertheless, the true challenge for Europe was the concept of multiculturalism in whole its aspects pointing towards cultural diversity. This concept has found its true challenge within the area of religious diversity, religious tolerance and coexistence surrounded by situation where two super religions share vast history of antagonism and dominance one over another.

Discussion that has appeared considering the following subject is rather intriguing, founding its core among awareness of these religious doctrines in their capacities for tolerance and coexistence inside multicultural ocean of possibilities. What has reality to teach us these days is a crack in religious coexistence worldwide that gets deeper and deeper every minute. The vision about civil society where economical welfare of its subjects is a priority and where specific attention has been paid towards cultural and religious aspects of its fellow citizens has come to particularly difficult terrain considering the case with Turkey: constitutionally secular country with predominant Muslim citizens that has expressed its aspirations and will to become a rightful part of European Union. What is certain, the concept of unity in diversity has questionable commodity by this perception of religious diversity. Turkey has entered the twentieth century as constitutional secular country that guarantees freedom of religion for its citizens. Statistically, Turkey has a high majority of Muslim citizens: $96.4 \%$ Muslims from which $73 \%$ are nonreligious Muslims (Country - Turkey, 2014).

(C) Authors. Terms and conditions of Creative Commons Attribution 4.0 International (CC BY 4.0) apply. Correspondence: Dragan Kostovski, E-mail: kostovski.dragan@gmail.com. 
In its structure, Islam has certain elements of warlike religion. There are examples where Holly Koran calls for its believers in holly war against nonbelievers. Part of that is true but for complete understanding of these situations we must consider the historical context and social circumstances of the formative period.

Islam subjects its followers to strict discipline so it could penetrate and thus affecting personal activities on daily basis. In such manner, personal life of the followers gets to be modulated in the way that is rather exotic in common western citizen context.

On the other side, European Union was created as an economic community of independent states. They unite themselves creating the Union in achieving greater economical in firs place, and thus cultural benefit for their subjects - citizens of the Union. Not imposing its hegemony onto any other nation, the Union has created the highest principle - United in diversities. Virtually, one could found a lot of those qualitative diversities that could initiate possible fields of unity. Nevertheless, what appears to be the greatest hiatus in this context is more or less, on thing that is one and the same for all members of the Union, the religion. European Union is in a way a single religion union: all member states, all member nations are in a way, a Christian followers. Christian religion considering its denominations is a religion of the all EU member states. In our view, Christianity is a platform that shares a single ethical concept from Helsinki to Athens and from London to Kiev.

\section{European integrations and Islam religion}

Solemnity of the subject was raised with the question of Turkey mining its aspiration for full right membership. Turkey is happened to be a distinguished NATO member; its territory enters the European continent, and is not an EU member. Demographically, Turkey with a 97\% Muslim population, appears to be a symbol representing the others, the others with other religious beliefs, and that other is not just other but is Islam: an Abraham religion just like Christianity is, that share rather terrific war history with more than a few attempts for geopolitical and social domination. What is obvious and manifest quality of Christianity is the spiritual message of love and compassion, brotherhood and serenity. This Christian ethic is more or less represented in all its denominations. And what is served today as a spiritual message of Islam, well slightly different, irrefutable obey towards holly scripts, the Sharia law that's normatively prescribes and affects every particular aspect of the follower's life. Charging with such normative concept gives a dose of certain manipulative collective consciousness and a risky lack of individual, more logical decision making considering a wider social perspective. In the end all one can expect is a highly manipulative society.

Critical analysis in this area having in mind the formative period of Islam religion points to a certain spiritual core that is consisted of strong ethical principles toward individual development and treatment of other fellow citizens, especially the ones having a different religious believes. This is the introvert aspect of Islam that as the time passes by has more and more latent appearance in spite of more dominant religious jurisprudence.

Heading towards religious tolerance and respectful coexistence in this manner, our vision must pierce throughout this barrier built by Islamic law. Within our first critical steps towards Islam what is obvious is the message of spiritual and ethic perfection of its followers, a concept quite similar with Christianity. Islam promotes love and compassion, ascetic life and tolerance towards other people. What is different here, compared with Christianity, this ethical concept is promoted in rather different way. It is Sufism and Sufi groups where those aspects of Islam are located. Ever since the early beginnings Sufis were important part of Islam.

History speaks of high level importance in this aspect for consistency of Islam. The formative period is a particularly rough and turbulent situation in Middle East area that was 
populated with various Semitic tribes that were engaged in time long battles in-between or with other civilizations for hegemony in the region. In such situation of constant virtually never-ending violence, basic teaching of Islam gets to be divided in various similar teachings in struggle for attracting more and more followers. This is especially the case in first three centuries after the prophet Muhammad. In that time Islam spirituality and mysticism are quite dominant and is manifest part of this newborn religion. Hence, Sufism played the most integral and comprehensive role for what is considered to be later an Islam religion. This defensive position once taken by Islam's spiritualism and mysticism will be manifested again in late middle century when after that it slowly begins to be marginalized.

\section{Sufism: Not just a part from Islam religion}

Today, besides remote connection that exists between Sufism and Islam according to some scholars, it is evident that Sufism is immanent part of Islam. Although there's vast number of examples where Sufism is marked as everything but Islam, what makes it immanent for Islam and no one will deny that is the principle of purity of faith or al-ihsan, which has a central role in all Sufi writings of wisdom. What is meant by this purity of faith? What is so important about it? Purity of fait when considered by Sufis means immanent awareness for individual behavior that anticipates a divine presence in every mental and physical action. This awareness is not interrupted by ego's desires, by the past actions or future plans. In such manner, Sufism is representing the core of Islam as a human religion that is dedicated for preparation of the followers towards ultimate divine presence.

This dialectic woven that exists between Islam and Sufism needs a precise analysis of the history of Sufi orders, especially at the time of early beginnings - the time known as a formative period: time when Islam was founded in Medina where Muhammad created the first Muslim community in $662 \mathrm{AD}$ and where he personally have educated the first generation of Muslims.

According to the written texts that are describing this very moment of early days in Islam, in one private situation when Muhammad was in divine mystical presence of Angel Jibreel (Archangel Gabriel - The divine messenger in Christianity), the Prophet was asked to describe the three most important aspects of the faith, on what he give the answer by numbering them in order (Baran, 2004, 4):

- Al-Iman, which means to have thrust in divine deity, in divine angels, in divine books and messengers, in Judgment Day, in divine path that leads towards divine presence and to have trust in divine order that affects everything and everywhere;

$\circ$ Al-Islam, which means practice, and refers to withstand that there's no other but divine deity and Muhammad is its prophet, to offer a prayer and to express mercy, to practice fasting in ninth month of Ramadan, and to visit the divine house in Meka, known as pilgrimage and represents the symbolical quest of the followers for the holly trail;

- Al-Ihsan, meaning the purity of faith, and is described to believe in deity as it's stands visible right before the eyes, and if one can't see the deity to be certain on divine presence in every action.

During the first centuries Islam has a rapid expansion that was followed by intellectual glaze, high crank was to be presented by devoted Muslims, intellectuals that gave special effort towards systematization and codifications of what will be come to be a new mega religion. Like so, this group of new teachers - Ulama begins to specialize in certain areas that are of practical importance for everyday life of the followers as in particular that is the case with the standardization and memorization of the Holly Quran, widespread studding of the Arabic language and grammar, which therefore contributed in exact interpretation and recitation of the 
Holly Quran and Holly Scripts - Hadith. In such manner, all of that effort helped in creation of widespread, rather orthodox belief system that was contrasting the heterogeneous and heretical groups and this system in major contributed for codification of primordial, rather basic way of Islamic daily life, known as Islamic jurisprudence or Al-Figh. What followed in terms of further effort was anchored on early attempts for standardization of Holly Quran, attempts to establish the teaching, and collections of eligible texts and writings of Hadith. In short, establishing of specific orthopraxy - Al-Islam and specific orthodoxy - Al-Iman have occupied the attention of majority religious scholars of the time.

While sensing the possible danger in this tendentious and exclusive religious scope of needs and demands that in a way has pointing toward surrounding settlements, certain Muslims have undertaken actions in clarification and codifications of the basic teaching, actions that in time became a complementary discipline directing the inner life of the followers or Al-Ihsan, a discipline that was rooted inside Holly Quran, particularly in prophet customary and his closest followers. Certain scholars will name this discipline as Afterlife discipline. This discipline included one practically action-directed or pragmatically knowledge that incorporated a highly ethical aspect and was focused toward purification of the heart, but also and theoretical dimension that represented the mystical part of the teaching. Acknowledging the current situation, where the need of pragmatically directed jurisprudence was essential in supporting for this new religion, these scholars of the inner way shared the opinion how manifest elements of this teaching were insufficient and in doing so they pointed the attention towards exploration of attitudes, intentions and mental conditions that are crucial for purification of the hearts and their direction for at some point starved, divine way. Like so, the sphere in which these doctors of afterlife were exercising their authority and their judgment was the invisible dimension of the heart, a rather subtle area that is out of physical perception and yet touchable for spiritual experience.

In time certain leaders will achieve to become a perfect scholars and practitioners of this discipline. Until the twelfth century there were recognizable a certain groups in which spiritual core were Sufi aspects. Each of those groups was to be guided and represented by a grand leader or Sheikh followed with a personal appointed represent or Caliph for each generation. Spiritual eligibility of each Sufi order was proven with the existence of the uninterrupted line of spiritual teachings and formations that were transferred from one generation to another, carrying their beginnings all the way back to the time of the prophet and from the prophet Muhammad himself.

Sufism, in such manner has spread not just theologically but also as a social movement that with each one group of followers was affecting substantial mass of people. With further enlargement of the followers, these leaders have gained with tremendous amount of power and authority, as in spiritual manner but also as physical control of the masses. These leaders was given the thrust and respect of the thousands of people, ten thousands of followers were in their hands and each one has given the vow of divine obey, which was represented by the prophet whom represents the Sheikh that's in a way represented by the Caliph.

Sufism that helped spreading the Islam in Central and Eastern Asia, South-East Asian archipelago, Indian subcontinent and sub-Saharan Africa was social and spiritual power. Thus, the legacy was the Islam: religion that preached with cultural sensitivity, religion that promoted tolerance, inter-religion cooperation and has never traded the inner life dimension and spiritual core for any kind of sole political activism (Karamustafa, 2007: 47).

Middle age Islam spiritualists built the Sufi orders mostly to help the followers in achieving the highest level of efficiency during their travel and quest for the kingdom of what is invisible. Having in mind the importance of qualified leadership in this quest, the great Muslim mystic and writer, Rumi will point that walking the road without a guidance one will need a hounded of years for a two days journey to be completed (Baran, 2004: 6). 
In essence, this journey is a struggle - Jihad against all the human weaknesses. Quran speaks about human souls, Nafs that are under the command of evil as one of those weaknesses. This struggle continues thought eternity of life just like soul remains with the body until death. That is the case also with those that have achieved the highest level of proficiency. That struggle isn't directed towards human soul but against all evil habits. In constant following of those efforts, Sufis undertake the speech of the prophet as their base point, especially the speech where Muhammad qualifies the human soul as men's dangerous enemy.

This struggle is a medium that Sufis are using to reach the highest level of proficiency which they are calling a perfect man or al-Insān al-Kämil (as it was mentioned above, the inner proficiency was one of four most important aspects of the faith for which prophet Muhammad was asked). Here though, spiritual tradition of Sufism is represented by three different levels of dedication:

- Ilm-ul-yaqeen, competence through learning;

- Ayn-ul-yaqeen, competence through contemplation and visualization;

- Haqq-ul-yaqeen, competence through experience.

The last one is considered to be the highest form and is also described as a divine knowledge that couldn't be achieved by all Sufis but a thing that all Sufis are headed towards.

Ali, the fourth caliph and prophet's brother in law gives a substantial personal example for this level of faith. Ali would say: "If the veil of unseen gets opened, the strength of my faith will not increase" (Baran, 2004: 6). In other words said, his faith was so powerful that even the divine image will not make it stronger. This is the reason why Ali is considered as a Sultan: ultimate spiritual leader of all Sufis.

Since the figure of Ali is of significant importance for Sunni as well as for Shia Muslims, it is very important that this significance could be used as a bridge of unity between those two traditions. Sufis in Sunni tradition are paying a huge importance considering the figure of Ali. In this manner, Sufis could promote dialog among Shia and Sunni - traditions that are politically opposed and yet theologically identical.

As a primary source of Sufi are considered the holly Quran and Hadith. Nevertheless, there are similarities that suggest the closeness with Judeo-Christian tradition. Later Sufi tradition has elements as a consequential influence of close examples of converted Judeo and Christian spiritualists but also by wide cultural interaction that will continue throughout seventh century and also during the period of Crusade wars. As a result of this wide interaction a lot of Sufis consider Jesus (Isa) as a prophet, and took its example as important spiritual example. There are also Sufis who continued the tradition of celibacy in a way as continuity of Jesus celibacy. Nevertheless, besides the fact that Muslim were interacting with Christian and Judeo mystics and spiritualists, and they were also giving a high respect in this manner, what is considered as a main source of Sufism are the holly Quran and the holly writings, Hadith.

Most of the Sufis remained faithful for basic teachings in Islam but these contemporary processes of social development exposed the new challenges in their life. As for example, Turkey has left the Sufis, rather dramatically in first decades of $20^{\text {th }}$ century and there are still Sufi orders who try to adapt to the modern life challenges. The Naqshbandis have kept their popularity in political also cultural life in Turkey. Other Sufi orders have their newspapers, journals and various financial institutions.

There are some religious oriented civil movements, technically not considered as Sufi but their ordinary traditions incorporate Sufi elements as a part of their spiritual life. In this manner, it's to be mentioned the followers of Fethullah Gulen. This movement is promoting a rather conventional, version positioned between modern life and Islam spirituality. This 
movement has a structural differences compared to other Sufi orders, especially in its lese fer internal structure with lack of hierarchy. Nearly the same as other Sufi orders, this movement has kept the dimension of heart in its teachings. Simply putted, this movement is in quest for universal balance. The founder of this movement is not to be considered as a Sheik or a leader of Sufi order but he is the author on many writings that are pointing toward Sufism. In other words, this could be understood as a new form of Sufism, namely neosufism (Faghfiory, 2003: 28).

Considering the future, the traditional way of Sufism will reconstruct itself according new and modern demands. As a spiritual form of Islam, it is certain that Sufism will have prosperity, although less potent and latent. That explains how neosufism will attract certain publicity making its moves through spiritual aspects in social, political and economical dimension.

Throughout the history of there were visible tensions between Sufi and Islam scholars considering whether the Sufism is or isn't founded in holly Quran and Hadith. These currents are divided in two groups:

- Those who reject Sufism as a Islam related;

- Those who reject Sufism in aspects of modernity.

First group correlates Sufism as a sort of quasi-religious innovation directed against Islam and its teachings, and the second claims that Sufism is a loosely beneficial as a popular religious view, simply putted as a form of pacifism that resulted with continuous backward of Muslim society in contemporary era of science and technology.

As a core base in this tendency appears to be the fact that most prominent religious leaders have their interests inclined towards Sharia law, and the thing about Sufi is they highly respected the Haqiqa - the mystical truth. Islamic scholars seek for obedience for Sharia from Sufis. Nevertheless, significant number of Sufis saw the codex as a rather irrelevant and pointless, heading their interest for the rational aspect of Islam that was described in the Holly Quran. Sufis believed that the holly scripts - Hadith were encouraging the Muslims for rational and critical approach in their quest for the meaning of holly creation. Some Muslim scholars followed this way directed by the holly scripts. Likely, Islamic jurisprudence and most of the Islamic thought were produced as a result of such academic efforts.

Today this tension is following a rather extreme path as a complex struggle between Wahhabism and Sufism.

This new ideology, in a common manner called Wahhabism - today is occasionally referred as Salafism ${ }^{1}$, was explained as a new form of purification of the Muslim praxis around the world, purification from the Sufi influence mostly but also from interferences of other religious beliefs mainly originating from the West. This new ideology locates the failure in its activities as a result of corruption of the faith. This corruption is based with the attitude that Muslims are very permeable considering new cultural trends, referring the modern social currents that are influencing and penetrating the Islam. As a consequence of such reality, these people have made themselves worthy for God's wrath.

Sudden success of this political fundamentalism could be explained with possibility of uniting the common cause capable to confront the West. The solution was relaying their activities on Holly Quran. Aiming to exploit the Holly Scripts - Hadith, a maneuver has been made to redefine the Islamic law based on literally translations, literally and sole implementation of written

\footnotetext{
${ }^{1}$ Salafi movement is often erratically described and used as a synonym for Wahhabi movement, but Salafs are considering this comparison as rather humiliating - as stated by Roy (1998). As a distinctive quality compared to Wahhabis, the Salafi movement is a group of highly educated and puritanical Islamic activists.
} 
religious traditions were product of social situation during past centuries. Speaking of which, a common complex situation that overwhelms the common reader has arose: the Holly Scripts are explaining about ancient times, time when the Prophet walks the Earth, they do incorporate plenty of practical life solutions that are logical for the time when they were made and find their sense back in the days described as a Formative period of Islam religion. This solution has its success. Nevertheless people didn't realize what Wahhabist did was a sole reinterpretation of pragmatically theological and jurisprudential solutions that were there for years and centuries ago and mainly made for certain time with a certain social and cultural situation in the history. What was here done by Wahhabists was a solemn import of historical praxis in a totally remote in time societies, in contemporary social and cultural context. This situation had appearance of an effort made to perform a sort of faith purification.

The process of globalization in all its complexity is active on the world scene from the second half of $20^{\text {th }}$ century and its effects are manifesting in virtually every aspect of human life, have brought the discourse: considering the relevancy of many practical questions directed towards foreign policy, closer to national security and international relations. In this manner there are a few things to be underlined.

In Christian Europe there was an early days attempt to be understood a thing or two about Islam, for classical Arab literature etc. This attempt can be traced earlier at the time of the high middle century and is based on rather solid, more practical observances on the whole thing here. Nevertheless, Islam warlords have attacking Europe, and Europeans were sensing that something must be done. Islamic studies have continued in this manner were not stopped with the fall of the threat. After the $16^{\text {th }}$ and $17^{\text {th }}$ century till and on, there were departments that were studding the Arab culture as a part of European universities. First department of such kind in France was established at the beginning of the $16^{\text {th }}$ century. First military invasion of France inside Arab world was in Egypt at the end of $18^{\text {th }}$ century. Important thing is that French men were studding the Arab language and departments of such kind were established as a result of considering the Arab language as biblical language, a classical language together with Latin, Greek and Hebrew. What was missing here, were the studies, considering Turk and Persian language and culture. As main reason for this were university studies: they weren't upholding in these languages. Studding Islam was to be continued in many attempts for its understanding, an approach what we now recognize as orientalism.

But all of that in a way didn't correspond with West. Pointing a different aspect, there can be found a total lack of interest considering this subject within European perspective until the moment when attention has arose following the imperial conquests and race for territorial and social domination. While European orientalists were studding classical Arab language and closely studding the Holly Quran, the intellectual base of the Middle East that was occupied with European languages was only concentrated toward contemporary issues. For example there was a substantial literature for the period of $18^{\text {th }}$ and $19^{\text {th }}$ century published by distinguished authors, European Christians and Jews, concerning the Islamic law and theology. What is a rarity is to find a certain comprehensive study of Christian doctrinal theology made by a Muslim author. It just seems like there's no particular interest for making such effort. Simplified, we are talking here about difference in perception.

Modern times are speaking the global tolerance; we also sense thing or two for legendary Spanish Islamic tolerance from the Middle Age. This correlates that tolerance is in essence a particularly intolerant ideal.

In rather simple understanding, one could defy tolerance as a particular allowness on part but not all of the rights that are enjoyed until certain rules are being followed. This looks like a fair definition of tolerance according to European practice but also in other parts of the world. Obviously it's a lot better than intolerance. If there could be made a comparison between Ottoman 
Empire and these days Europe, or modern West, all the odds considering tolerance are on the Ottoman side. Word is, Jews had a shelter inside the Empire, or in other Muslim societies around Northern Africa. In fact that was a stratified citizenship, anyway more than nothing.

What is obvious, Sufism is a concept that is acting as a social power that in first place connects the people, affecting the interpersonal relations. Acting as a bridge among other, different nations and cultures, gives explanation about its success in every part of the world. Becoming leaders of nation is not a Sufi objective, but to become society builders. Sufi harnesses themselves with other people from certain society thus learning their certain cultural traits. They do promote communication among people and this was especially notable when traveling was not a visa restricted. Considering Sufi social actions, we can trace in many societies the beginnings of interracial marriages originating from Sufi ethical aspects.

The holly writings - Hadith are teaching to have faith in the prophets and to challenge ourselves in making pleasant and trustfully relations with all creations in this world because behind every creation there is divine purpose. These actions include Jews and Christians respectively: Don't disappoint them because if you do, social problems will multiply till eternity (Baran, 2004: 19). What Quran teaches and that resembles one of the five pillars of Islam is to worship divinity as they see it and if they don't see it for sure sees them. This could be understand with a little touch of mysticism, meaning that if supernatural is out of human perception, what is visible are its signs.

Sufi has a rather different way in perceiving and understanding on these things: If one doesn't see himself (egocentrically), if one relocates its desires in absence, then he will be able to perceive divinity. Furthermore, for sure it will be perceived divinity in each and every individual - it must be seen because what Sufi teaches is to recognize every single one thing as a consequence of a divine effort. This is the aspect that keeps Sufi untouchable considering what would be ethically inappropriate behavior.

In other words, Sufis doesn't need to spread their heart's love with any means of weapon. Sufis doesn't have any armies and in their relations they are using spiritual means. Namely, Sufis have attacked thousands of followers with their tradition in Central Asia, Indonesia, South-East Asia, Turkey and Europe.

Today this is not the praxis mainly because Islam is closely identified with nationalism. In the beginning of the $20^{\text {th }}$ century during popular uprisings against European colonization in Muslim world, Muslim intellectuals were headed towards Quran implication in a way that will attract a higher level of support worldwide. Following such actions Sufi teachings were completely thrown in shadow forgotten by daylight of the period. As a main examination for such actions was continuity of the religious struggle with the West. This Wahhabi resistance, this movement in the end will claim the right to represent the Muslim world.

Wahhabism has a central position inside Islam religion, maybe as important as a main tradition in certain time, and compared with Christianity is similar to Ku Klux clan in USA. Major difference between these two religious groups is in circumstances that affected the Wahhabis and luckily as praxis didn't happened with Christian world: the change in the house of Saud and local tribal Sheiks in Necd according to Wahhabi doctrine in $18^{\text {th }}$ century, the establishment of the kingdom of Saud in 1920 s that incorporated Mecca and Medina, and perhaps the worst of all, the importance of oil as valuable energy source. This meant that all the sudden the Wahhabi monarchy was washed up with fresh oil cash and was in control of two the most holly places in the world for Islam religion, and this meant dominant influence on to the fifth pillar of Islam religion, the pilgrimage.

What is notable are the difficulties that Westerners have with understanding the importance of pilgrimage for Muslims, considering that there's no exact similarity in Christianity 
and western history. Well it's understandable that Christians do have pilgrimage as a ritual praxis but these rituals are mostly individual quests that are made in individually selected moments and mostly for individual purposes.

On the other hand, Muslim pilgrimage was and still is a well organized group activity that has a strict time - period of each year for it to be performed thus attracting followers, believers, Muslims from every corner in the world at one and the same place. Pilgrimage created a certain level of communication within Muslim world that has no adequate parallel inside Christian world, that will induce the same social transmission effect in this numerous homogeny population, at least till mass media era took its grip. Each year Muslim believers come and took part in common ceremonies and naturally exchange knowledgeable information. This is what we call interpersonal communication within Muslim world and through this custom of pilgrimage which importance is a bit difficult to estimate when knowing that its effect has a merchant value. And when the house of Saud took over the control of the pilgrimage, the Wahhabi influence arose. It would be just enough to add the oil cash income in this situation to understand the outcome: transformation in to world power country of what otherwise would be a mind sick sect on the edges of a marginalized country.

Following the conclusions, the story of one Chinese Muslim that was caught in a temporary visit of Indonesia and in discussion considering the Chinese religious policy in the time when government activities were headed towards Islamic population, he explained that in fact Chinese authorities were took an extreme actions in closing down all Wahhabi mosques in China. On the question to give a clarify on which group he belongs, man answered that he is a Sufi from Uigur, so he made a clear statement that Chinese authorities didn't had any issues what so ever with Sufi groups until they stay clear off Chinese governmental policy. Here's his statement (Baran, 2004: 20):

"The only problem that we encounter today in China is the one with the pilgrimage. In early days people go in thousands in Saudi Arabia and all the pilgrimages were encountered at Jeddah by the Wahhabist and they were giving the pilgrimages various literature brochures. All the sudden pilgrimages took their path in direction of Wahhabi doctrine, so the came back in China to destroy our temples and shrines, to burn our writings. This is how our thousand years old Muslim civilization becomes ruined by Wahhabist".

If Wahhabi movement can penetrate such enclosed Chinese country we can only imagine the situation with western democracies. Prior to 1960 s there were no identified at least such major issues with Western world. Then teachers and activists of Wahhabi start to spread this doctrine. Their actions gave the thought that Sufi concept was a rather weird form of practicing Islam religion. What is obvious is that what one can see traveling around the world and that is the reality of Sufism as an integral and crucial aspect of Islam religion as a whole. Namely, Indonesia has fifty millions of Naqshbandi students and twenty million followers of other Sufi brotherhoods; furthermore this number is similar with Malaysia, Brunei and Turkey. Even in Saudi Arabia there are Sufis, and they are being forbidden public practice.

Nevertheless the example with USA gains on relevancy, namely the situation whether the US will give support on Sufis or will they cooperate with Wahhabis. If second to be chosen there is a risk tendency in cooperation with terrorist organization; this isn't the case with Sufis. The case is very simple at this point: USA must reach and give support to non-Wahhabi Muslims if they wish for success in this struggle. What we're facing here is a proposition with no shortcoming. 


\section{Exceptional cultural integrative dimension of Sufism}

But Sufism is exotic. Sufi offers something different than just tolerance. The approach toward followers of other religions that is shown in Sufi writings is unmatchable. We're not talking here just about tolerance; we are talking about acceptance and inclusion in every aspect of social life. There are certain poems of Rumi, or Ibn Arabi written on Persian or Turk language respectively, that are indicate that all religions in essence are the same. All religions have the same goal, same message, same communication, and they all glorify same divinity, but the path they pass achieving their goals is different. Furthermore, this path is different for each one follower individually. That is the idea of centripetal dispersion of the thought and action of every one Sufi brotherhood, on every one Sufi order: the path towards the center or source is never the same for each two individuals and this is to be respected. What is the same is the ultimate goal that is final and eternal. The way Sufis perform their rituals is different and distinctive but divinity is equally present in Churches, Synagogues, and Mosques etc. Seems that this concept of acceptance, as a bit different as solemn tolerance is crucial benefit and it could take significant role with establishing better relations within and between communities not just for today, but in future also. If we look the Ten Commandments for instance, what is notable is that they all mainly refer on relations among people and just small portion is faced toward divine relations. Most of them prescribe the mutual relations among men. Today, in everyday Islamic text within Muslim communities enormous accent is placed on relation among men and divinity. In this manner Sufis again make a balance: Sufis point the scales towards men to men or intrapersonal relations. They are also dedicated in actions among men and not just divine relations. There's a notable Indian Sufi, Sheikh Saraffadin who gives a rather dramatically explanation on this concept as a whole. Namely, the Sheik speaks of the hard times and insults that are present among men and how they are more serious and having deeper consequences compared with sins against divinity. That means if a person does a sin against God, that person hasn't done any particular damage so forgiveness may be granted in some divine way, but the damage done to other man, brother or sister could be uncorrectable (Baran, 2004: 19). In such case the question of forgiveness could become really complicated. All this looks like a pretty interesting benefit towards moral debate at a highest level.

\section{Conclusion}

The quest for integration potentials of Sufism in achieving the highest level in process of Euro integrations, in managing the following processes of cultural integration have brought us to the ultimate message that one school can emit, and that would be ultimate respect for every creation as a result of divine effort, empathy and compassion for ones close to us, our neighbor and fellow citizen, our companion. That would be the basis, the cause and ultimate goal of Sufism. That is the potential of Sufism. That is the message emitted by Sufis embraced with a touch of extraordinariness. This is how we find the centripetal course of the Sufi's creative thought.

Considering the epistemological approach, there could be nothing more important then knowing yourself, achieving higher conciseness, more human conciseness then what one have yesterday. In present day global situation, this precious message that Sufis deliver towards global chaos was recognized by USA where Sufism has its social peak in popularity. We are not talking here about any sort of wide spreading certain religious beliefs. What we are talking here are intrapersonal relations within global multicultural social situation where everything has its place on the table. This is where US society has sawn the current situation and their advantage is having face directed toward the World. In such manner we should perceive modern society: as a society opened for the World as a whole, and this is the point where Sufis brought the crucial message. Sufis but not as the first who have found the peace inside the heart, but as the ones who widespread flow the open sea of diversities thus teaching in one and universal equality. 


\section{Acknowledgements}

This research did not receive any specific grant from funding agencies in the public commercial, or not-for-profit sectors.

The author declares no competing interests.

\section{References}

Almazova, L. (2014). Islam in multicultural world: Muslim movements and mechanisms of reproduction ideology of Islam in the modern information space. Kazan: University of Kazan.

Baran, Z. (2004). Understanding Sufism and its potential role in US policy. Washington: The Nixon Center.

Beyer, P. (2013). Religion in the context of globalization: Essays on concept, form, and political implication. Oxon: Routledge.

Brown, B. W. (1987). Quran, the Holy. Medina: King Fahd Holy Quran Printing Complex.

Casanova, J. (2004). Religion, secular identities, and European integration. Transit 27 (07-2004). www.iwm.at/r-reflec.htm.

Cheney, D. (1993). Defense strategy for the 1990s: The regional defense strategy. Washington: Congres Library Press.

Corbin, H. (1962). History of Islamic philosophy. London: Kegan Paul International.

Country - Turkey (2014). Joshua Project. www.joshuaproject.net/countries/TU.

Faghfoory, M. (2003). Kernel of the Kernel: $\left.A S^{-}{ }^{\imath}{ }^{`}\right\urcorner$ Approach to Sufism. New York: State University of New York Press.

Geaves, R., Dressler, M., \& Klinkhammer, G. (2009). Sufis in western society: Global networking and locality. New York: Routledge.

Karamustafa, A. T. (2007). Sufism: The formative period. Edinburg: Edinburg University Press.

Laipson, E., Kurtzer, D., \& Moore L. J. (1991). Intelligence and the Middle East: What do we need to know. Washington: The Institute For Near East Policy.

Roy, O. (1998). The failure of political Islam. Cambridge: Harvard University Press. 
Table and illustrations

Table 1. Turkey demographical structure: https://joshuaproject.net/

\begin{tabular}{|c|c|c|}
\hline $\begin{array}{c}\text { Number of People } \\
\text { Groups } \\
68\end{array}$ & $\begin{array}{c}\text { People Groups } \\
\text { Unreached } \\
46(67.6 \%)\end{array}$ & Progress Level \\
\hline $\begin{array}{c}\text { Total } \\
\text { Population } \\
80,369,000\end{array}$ & $\begin{array}{c}\text { Population in } \\
\text { Unreached } \\
79,766,000(99.3 \%)\end{array}$ & $\begin{array}{l}\text { Largest Religion } \\
\text { Islam }(96.3 \%)\end{array}$ \\
\hline $\begin{array}{c}\% \text { Professing Christian } \\
0.6 \%\end{array}$ & $\begin{array}{c}\% \text { Evangelical } \\
0.04 \%\end{array}$ & $\begin{array}{c}\text { Evangelical Annual } \\
\text { Growth Rate } \\
1.2 \% \\
\text { (Global Rate }=2.6 \% \text { ) }\end{array}$ \\
\hline
\end{tabular}

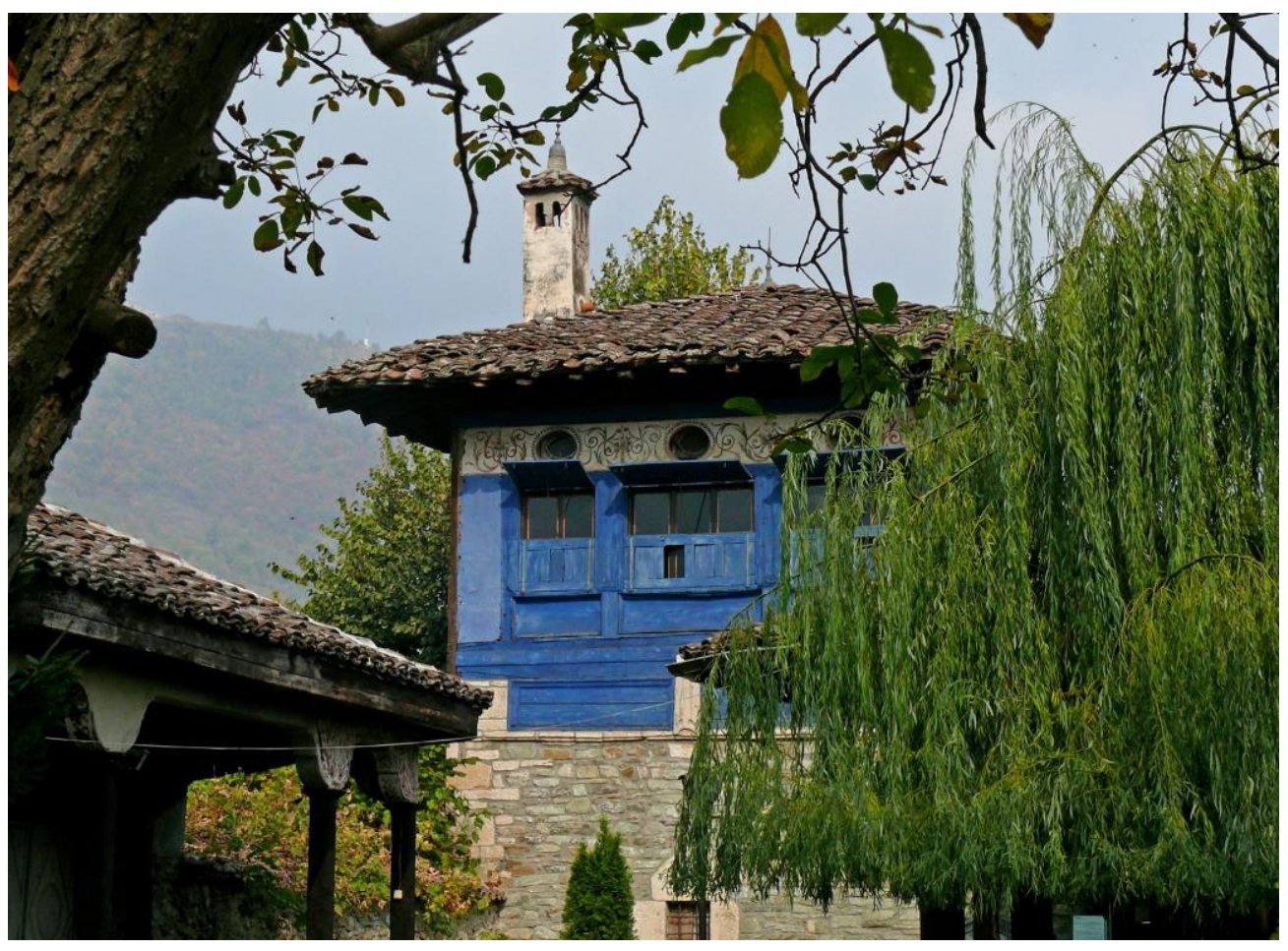

Image 1. Arabati Baba Teke, Tetovo, Macedonia.

https://commons.wikimedia.org/wiki/File:Arabati Baba Teke, Tetovo.jpg 


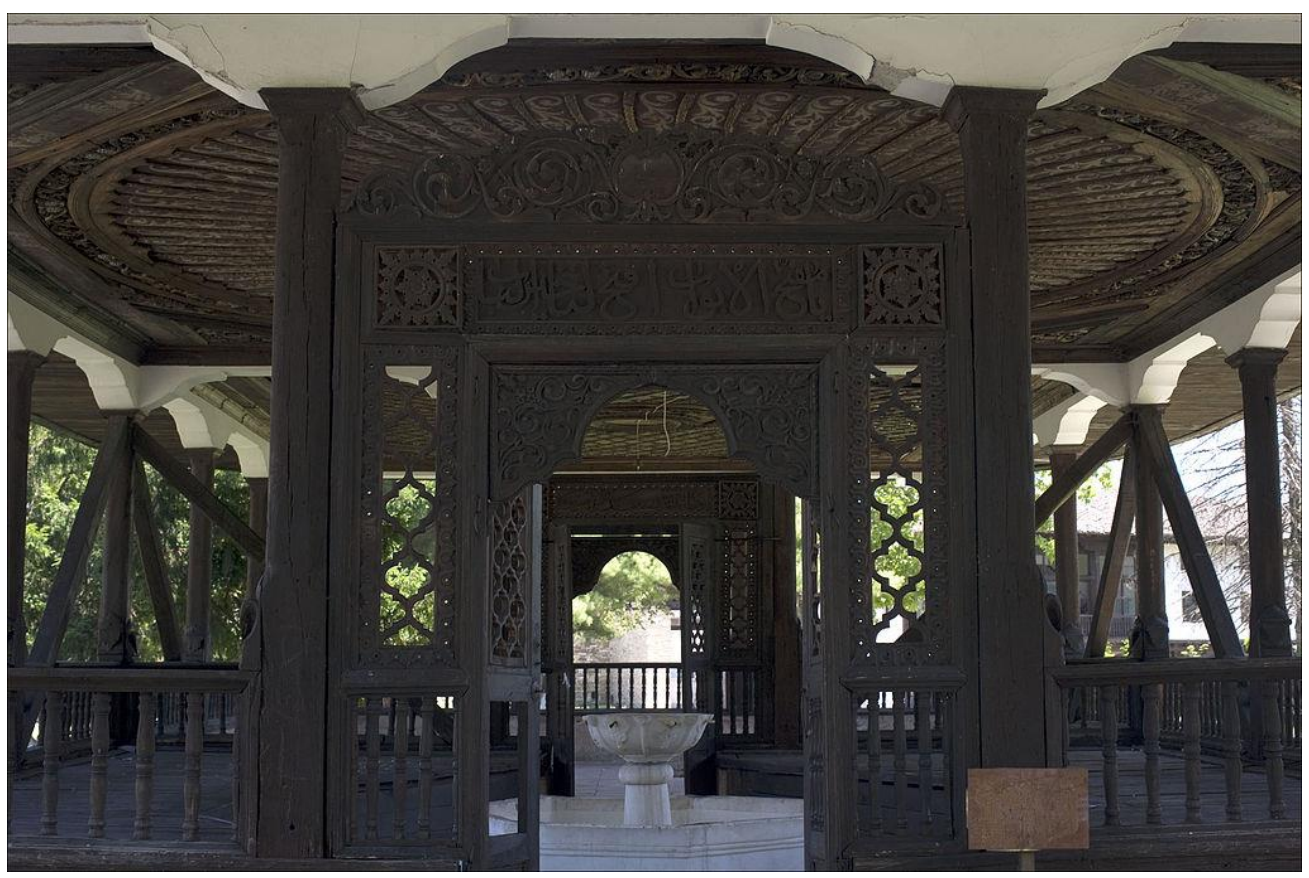

Image 2. Dervish Arabat Baba Teke, Tetovo, Macedonia.

https://commons.wikimedia.org/wiki/File:Arabati Baba Teke, Tetovo.jpg 
Dragan Kostovski - Sufism: A Cultural Integration Potential

C O A $\mathrm{s}$ 